\title{
A Study on the Epidemiology of Bovine Brucellosis in Punjab (India) Using Milk-ELISA
}

\author{
H. K. AULAKH, P. K. PATIL, S. SHARMA, H. KUMAR, V. MAHAJAN, K. S. SANDHU
}

Department of Epidemiology and Preventive Veterinary Medicine, College of Veterinary Science, Guru Angad Dev Veterinary and Animal Sciences University, Ludhiana, India

Received May 24, 2007

Accepted June 11, 2008

\begin{abstract}
Aulakh H. K., P. K. Patil, S. Sharma, H. Kumar, V. Mahajan, K. S. Sandhu: A Study on the Epidemiology of Bovine Brucellosis in Punjab (India) Using Milk-ELISA. Acta Vet. Brno 2008, 77:393-399.

Bovine brucellosis, caused by Brucella abortus, is a serious zoonotic disease manifested by reproductive disorders resulting in huge economic losses to dairy farmers. A random survey was conducted to study the epidemiology of brucellosis in Punjab (India) using sampling software Survey Toolbox. Two-stage sampling procedure was adopted; in the first step, villages were selected randomly from sampling frame of all the villages of Punjab followed by selection of owners, and animals in individual farms were identified using random sampling. In all, 32 villages were selected and then 345 animals (approximately 5\%) were sampled from these villages. The milk samples collected were screened for brucella antibodies employing ELISA test. The overall apparent prevalence of brucellosis was found to be $18.26 \%$ (true prevalence - 17.68\%). The prevalence in the central zone of the state was significantly higher, viz. $23.2 \%$ (chi square $=11.34$, $p<0.01$ ) compared to $14.2 \%$ in the sub-mountainous zone and $5.8 \%$ in the arid irrigated zone. The disease prevalence was found to be non-significantly higher (chi square $1.029, p=0.310$ ) in cattle $(20.67 \%)$ compared to buffaloes $(16.41 \%)$ and increased with age (chi square $=8.572, p<$ 0.05 ) in both species. There was significant association between disease and abortion (chi square $=22.322, p<0.01$ ) and maximum abortion cases due to brucellosis were found in $>6$ month of gestation $(95.7 \%)$. The disease was significantly associated with the retention of placenta (chi square $=8.477, p<0.01)$, however there was no significant relationship of the disease with repeat breeding (chi square $=0.044, p=0.834$ ). The results of the study suggested that the accurate epidemiological scenario of the disease may be obtained by employing multistage sampling procedures using milk-based ELISA.
\end{abstract}

Cattle, buffaloes, brucellosis, epidemiology, milk ELISA

Bovine brucellosis, caused by Brucella abortus, is a serious zoonotic disease manifested by reproductive disorders such as abortions, infertility, retention of placenta, stillbirth and calf loss in animals, and results in huge economic losses to dairy farmers (Radostits et al. 2000; Singh et al. 2002). Various studies have been conducted in India to establish the prevalence of the disease in bovines (Sandhu et al. 2001; Singh et al. 2004ab; Sharma et al. 2007) but these studies were based mainly on non-random sampling techniques. Hence the information gathered from such surveys cannot be extrapolated to apply to state or national bovine populations. Moreover, these studies were based on detection of antibodies in serum using conventional serological tests. The milk ring test is probably the most widely used test for the screening and monitoring of brucellosis in dairy cattle (Alton et al. 1988), but its sensitivity and specificity is questionable (Huber and Nicoletti 1986). In the last decade, several indirect enzymelinked immunosorbent assays (ELISA) have been developed and successfully tested on milk samples (Romero et al. 1995; Vanzini et al. 2001). The present study was designed to assess the epidemiology of the disease in the bovines of Punjab (India) using milk ELISA employing a multistage sampling procedure.

Address for correspondence:

P. K. Patil

Department of Epidemiology and Preventive Veterinary Medicine

College of Veterinary Science, Guru Angad Dev Veterinary and Animal

Sciences University, Ludhiana 141004

India

Tel: 91-161-2414030 (work)

Fax: 91-161-2400822

E-mail: pkpatilvet@yahoo.com

http://www.vfu.cz/acta-vet/actavet.htm 


\section{Materials and Methods}

Study area

Punjab is the north-western state of India bordering with Pakistan on the west and situated between the $29.30^{\circ}$ $\mathrm{N}$ to $32.32^{\circ} \mathrm{N}$ latitude and $73.55^{\circ} \mathrm{E}$ to $76.50^{\circ} \mathrm{E}$ longitude. Punjab state is broadly divided into 3 agro-climatic zones, viz. Sub Mountain Region (annual rainfall 800-900 mm), Central Plain Region (annual rainfall 500-800 $\mathrm{mm})$ and Southern-Western Region $(<400 \mathrm{~mm})$. Approximately $70 \%$ of human population live in villages and agriculture is the main occupation. India has 200 million cattle, 76 million buffaloes, 110 million goats and 46 million sheep, of which Punjab has 2.64 million cattle, 6.17 million buffaloes, 0.41 million goats and 0.44 million sheep. The estimates of milk, egg and wool production in 2003-2004 were 839.1 million kilograms, 3068 million numbers and 0.554 million kilograms, respectively (www.husbandrypunjab.org).

Selection of villages and animals

Villages form the basic geographic and administrative units in the state. To draw a simple random sample from the population of animals, two-stage sampling procedure was adopted. In the first step, villages were selected followed by selection of owners and animals and then animals were identified from the individual farm. A computerized list of the villages of the state was used as sampling frame and villages were selected $(n=32)$ from the whole state using simple random sampling, without replacement, using the 'Random Village' program of Survey Toolbox (Cameron 1999). The selected village was visited to prepare the sampling frame of all the farmers of the village having dairy animals. The animals were selected either using random number tables at the spot or in the laboratory using the 'Random Animal' program of the Survey Toolbox. Once the list of the owners and animals to be selected was ready, the farm of the owner was visited. As animals were not individually marked, the owner was asked to call out loud each animal. The animals were given temporary identification number based on the order of calling by the owner. Then the animal with a temporary number corresponding to the selected random number was identified. The total bovine population in these villages was 6980, of which 345 animals (approximately 5\%) belonging to various owners were randomly selected. The 150 cattle selected were mostly Holstein-Friesian crossbred, whereas 195 buffaloes selected were mostly of the Murrah breed.

Processing of Milk samples

About 20-30 ml milk sample was collected from each selected animal without addition of any preservative. Milk samples were kept on ice while transported and stored at $-20{ }^{\circ} \mathrm{C}$ until use.

\section{ELISA}

The samples collected were subjected to milk-based ELISA (VMRD, Inc-Pullman, WA, USA). Milk samples were tested undiluted after removal of the fat layer following centrifugation of milk samples. Briefly, $100 \mu 1$ of samples and controls were added to antigen-coated plate and incubated at $25^{\circ} \mathrm{C}$ for $30 \mathrm{~min}$. The plate was washed four times, and $100 \mu \mathrm{l}$ of diluted (1X) antibody-peroxidase conjugate was added to each well and incubated at $25^{\circ} \mathrm{C}$ for $30 \mathrm{~min}$. The plate was washed again, and $100 \mu \mathrm{l}$ of substrate solution was added to each well, and incubated at $25^{\circ} \mathrm{C}$ for $10 \mathrm{~min}$. Then $100 \mu \mathrm{l}$ of stop solution was added to each well, and the optical density (OD) was measured at $620 \mathrm{~nm}$. The mean OD of negative controls for each plate should be $<0.50$ and that of positive controls should be between $0.60-1.80$. For interpretation of the test results, SP value was calculated:

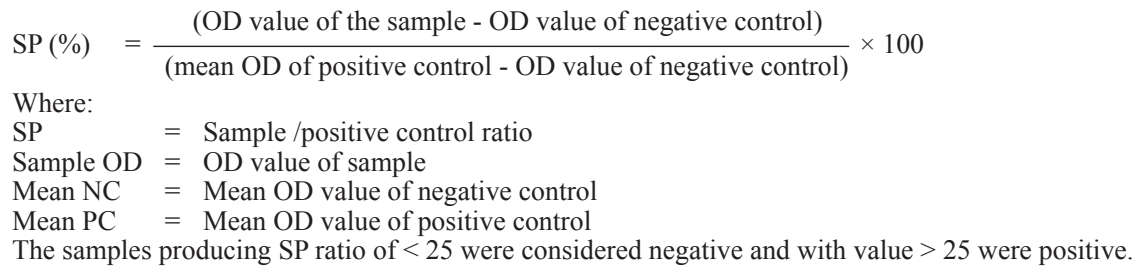

Statistical analysis

True prevalence was calculated at 95\% confidence interval (CI) using the 'True Prevalence' program of the Survey Toolbox, in which sensitivity, specificity and sample size were taken into consideration (Cameron 1999). A standardized questionnaire for animals sampled at the farms was filled in the time of blood collection. The data were analyzed using Epi Info 2002 (Dean et al. 2002) and SPSS (Statistical Package for Social Sciences) for Window version $11.0 .1^{\circ}$ SPSS Inc. USA computer software programs.

\section{Results and Discussion}

The milk samples from 345 randomly selected animals were analyzed with ELISA, which revealed prevalence of $20.67 \%$ and $16.41 \%$ in cattle and buffaloes, respectively; the overall apparent prevalence of brucellosis was $18.26 \%$. Given the sensitivity and specificity of ELISA at 100 and $99.3 \%$, respectively, true prevalence was calculated to be $17.68 \%$ 
(95\% CI 15.64-19.73). The prevalence in the present study is slightly lower compared to $22.5 \%$ reported by Gumber et al. (2004) employing milk ELISA on bulk milk samples collected from four districts of Punjab. Earlier studies have estimated the disease in the state from as low as 7.54\% to as high as $18.07 \%$ (Sandhu et al. 2001; Singh et al. 2004ab; Sharma et al. 2007). The variation could be due to different survey techniques employed by various workers. While the whole population was taken as target population in this survey, earlier studies were either confined to some selected farms or conveniently selected samples. The primitive Rose Bengal plate test has been used for analysis of samples in most previous surveys as compared to the highly sensitive and specific ELISA in the present study. The results of indirect ELISA (SP ratio) were plotted against the number of infected and uninfected animals (Fig. 1). Among the samples considered negative for antibodies to brucella, the significant number of animals had a SP ratio of less than $0(61.3 \%)$, followed by $0-10(27.7 \%)$ and $10-25(11.0 \%)$. Alternatively, among the samples diagnosed positive for brucella antibodies ( $S P$ ratio $\geq 25$ ), no significant peak was observed. The proportionate distribution of animals above the SP ratio of 25 clearly indicates that once the animal becomes infected, the antibody titre in the animal continues to increase till it reaches the SP ratio of 150 .

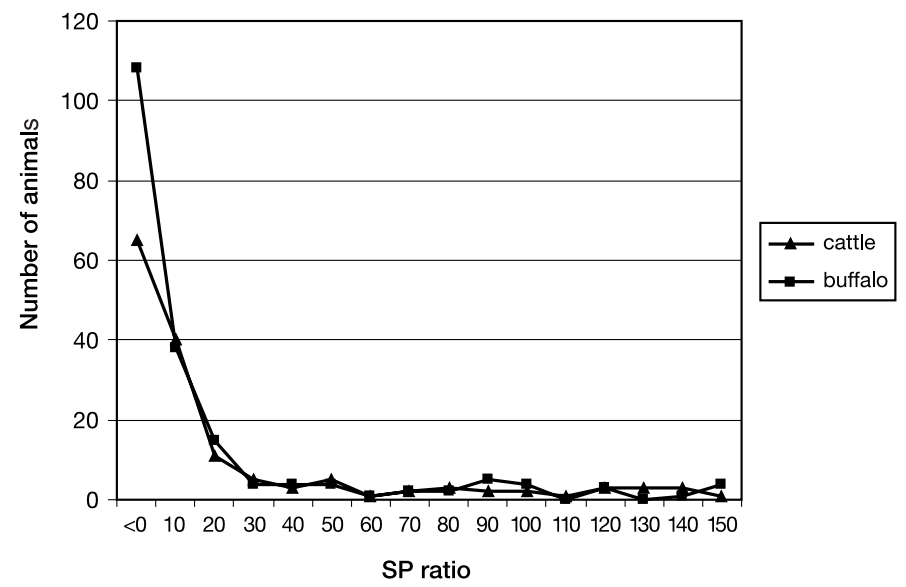

Fig. 1. Identification of uninfected versus infected animals in the bovine population

The prevalence in various districts had a significant variation. High prevalence was recorded in the districts of Moga, Ludhiana, Amritsar and Kapurthala (Fig. 2). All these districts fall within the central zone, which has significantly higher, viz. $23.2 \%$ (chi square $=11.34, p<0.01)$ prevalence in comparison to $14.2 \%$ in the sub-mountainous zone and $5.8 \%$ in the arid irrigated zone. The central zone is the most fertile and has large-sized dairy farms; as a result, maximum sales and purchases of animals occur in this zone of the state. Cow slaughter is banned in the state, hence the dairy farmers mostly sell brucella-positive animals in cattle markets and the disease gets transmitted to another farm. Furthermore, farmers usually do not screen the animals against brucellosis prior to purchase, consequently the introduction of a single infected animal at the farm leads to a storm of abortions in the herd. Earlier studies have also reported higher prevalence of the disease at organized dairy farms (Singh et al. 2004a).

Various host factors associated with the disease were studied so as to help in the formulation of a control programme. Species-wise (Table 1) disease prevalence was found to be non-significantly higher (chi square $1.029, p=0.310)$ in cattle $(20.67 \%)$ as compared 


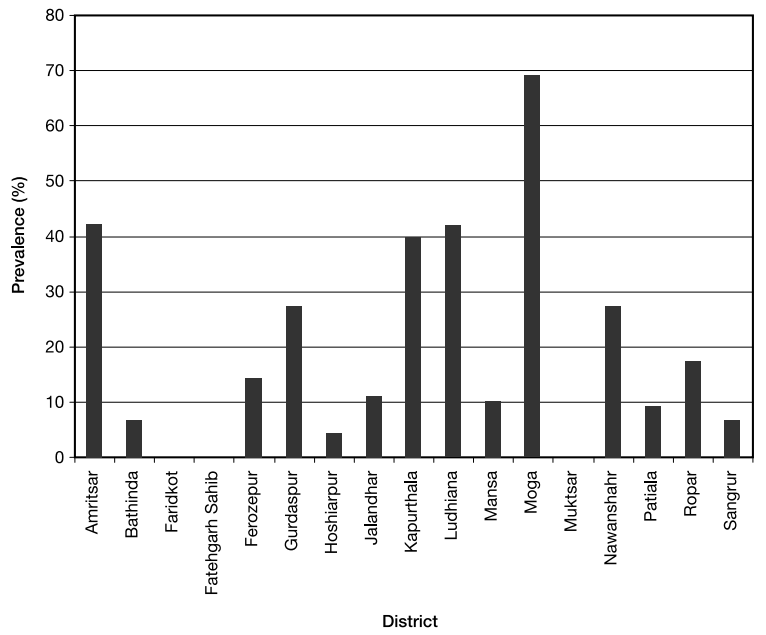

Fig. 2. Prevalence of brucellosis in various districts of Punjab

Table 1. Species-wise prevalence of brucellosis

\begin{tabular}{|c|c|c|c|}
\hline Species & Total & Positive & \% Prevalence \\
\hline Cattle & 150 & 31 & 20.67 \\
\hline Buffalo & 195 & 32 & 16.41 \\
\hline Total & 345 & 63 & 18.26 \\
\hline \hline
\end{tabular}

to buffaloes $(16.41 \%)$. Risk of disease was found to be higher in cattle (1.3 times) in comparison to buffaloes as revealed by the risk ratio and odds ratio. Similarly to the present results, most of the studies conducted earlier have also reported higher prevalence of the disease in cattle as compared to buffaloes (Sharma et al. 1979, 2003;

Chatterjee et al. 1986), whereas in contrast, higher disease prevalence in buffaloes in comparison to cattle was reported by some authors (Sharma and Saini 1995; Dhand et al. 2005). Thus, for any control program to be successful, both species will have to be

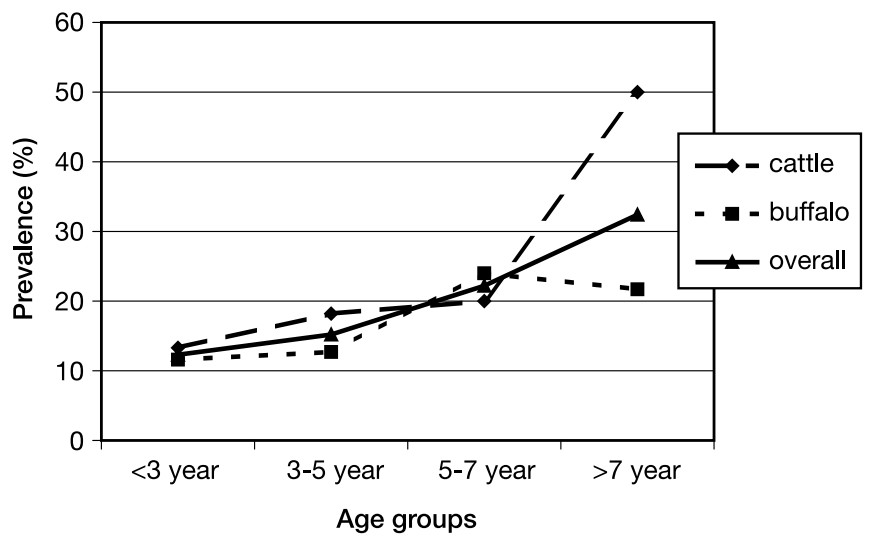

Fig. 3. Age-wise prevalence of bovine brucellosis 
Table 2. Association of brucellosis with abortion, retention of placenta (ROP) and repeat breeding

\begin{tabular}{|c|c|c|c|c|}
\hline History & Species & Total cases & Disease positive & Prevalence \\
\hline \multirow[t]{2}{*}{ Abortion } & Cattle & 31 & 13 & $41.93 \%$ \\
\hline & Buffalo & 26 & 10 & $38.46 \%$ \\
\hline \multicolumn{2}{|l|}{ Total abortion cases } & 57 & 23 & $40.35 \%$ \\
\hline \multicolumn{2}{|l|}{ No abortion history } & 288 & 40 & $13.89 \%$ \\
\hline \multicolumn{5}{|c|}{$\chi^{2}=22.322, p=<0.01$, Odds ratio $=4.19$, Relative risk $=2.19$} \\
\hline \multirow[t]{2}{*}{ ROP } & Cattle & 9 & 5 & $55.5 \%$ \\
\hline & Buffalo & 6 & 2 & $33.3 \%$ \\
\hline Total ROP cases & 15 & 7 & $46.7 \%$ & \\
\hline \multicolumn{2}{|c|}{ No ROP history 330} & 56 & $16.97 \%$ & \\
\hline \multicolumn{5}{|c|}{$\chi^{2}=8.477, p=<0.01$, Odds ratio $=4.28$, Relative risk $=2.75$} \\
\hline \multirow{2}{*}{$\begin{array}{l}\text { Repeat } \\
\text { breeding }\end{array}$} & Cattle & 23 & 2 & $8.69 \%$ \\
\hline & Buffalo & 18 & 5 & $27.77 \%$ \\
\hline \multicolumn{2}{|c|}{ Total repeat breeding cases } & 41 & 7 & $17.07 \%$ \\
\hline \multicolumn{2}{|c|}{ No repeat breeding history } & 304 & 56 & $18.42 \%$ \\
\hline \multicolumn{5}{|c|}{$\chi 2=0.044, p=0.834$} \\
\hline
\end{tabular}

included in the programme. The slight variation in results can also be attributed to species susceptibility, as cattle, especially the crossbred cattle having exotic germplasm, are more susceptible to stress conditions than buffaloes. Genetic differences in cattle and buffalo may be another reason for low prevalence in buffaloes.

Other host factor studies were the age groups of animals. In the present study, animals were grouped into four age groups, viz. $<3$ years, $3-5$ years, $5-7$ years and $>7$ years and the prevalence of brucellosis in different categories was found to be 12.3, 15.2, 22.2 and $32.4 \%$, respectively. It was found that disease prevalence increased with age in both species (Fig. 3). In animals of the age group $>7$ year, significantly higher prevalence of disease (chi square $=8.572, p<0.05$ ) was recorded. Lower prevalence of brucellosis in young ones could be attributed to resistance of sexually immature cattle to infection, which become susceptible to disease with age (Paul 1980), or passive immunization of calves through colostrum of their infected dams. Similar results had been reported by various authors (McDermott et al. 1987a,b; Ahmad and Munir 1995; Silva et al. 2000). Although susceptibility to disease increases with age, it seems to be more commonly associated with sexual maturity than age (Radostits et al. 2000).

Brucellosis is reported to cause abortion, retention of placenta, repeat breeding, infertility and prolonged intercalving period due to early embryonic deaths (Roberts 1999). Out of 345 animals screened (Table 2), 57 animals had a history of abortion and of these, 23 animals $(40.35 \%)$ were positive for brucellosis. There was significant association between disease and abortion (chi square $=22.322, p<0.01$ ) and the risk of abortion was 4.19 times higher in animals with brucellosis than without brucellosis. Similarly to the present study, Saini et al. (1992) reported 38.18 and $41.8 \%$ abortions in cattle and buffaloes due to brucellosis, respectively. The results are also in alignment with studies conducted by various authors (Jha et al. 1993; Srinivasa et al. 1999; Sandhu et al. 2001). The study confirms brucellosis to be the major aetiological agent of abortion in farm animals in the state. Out of 23 abortion cases due to brucellosis, maximum cases of abortion were found in $>6$ months of gestation (95.7\%), only 4.34\% in 3-6 months of gestation and none of the positive animals had history of abortion in 1-3 months of gestation. The higher incidence of abortion in the third trimester is due to the uterine environment conducive for the multiplication of the bacteria, which in turn causes foetal death and abortion by invading placental cotyledons and destroying villi. During the survey, retention of the placenta was noticed in 15 animals and of these, 7 animals were found positive for brucellosis. There 
was significant association between disease and retention of the placenta (chi square $=$ $8.477, p<0.01$ ) and the risk of placental retention was 4.28 times higher in animals with brucellosis than without brucellosis. However, the number of animals with a history of retention of the placenta was too small to arrive at a meaningful conclusion. In the present survey, 41 animals had a history of repeat breeding and out of these, 7 animals $(17.07 \%)$ were found positive to the disease. There was no significant relationship between repeat breeding and brucellosis (chi square $=0.044, p=0.834$ ) in the present study. The present findings are in agreement with Bachh et al. (1988) who reported brucellosis to be higher in cattle with a history of abortion (89\%) as compared to those with a history of returns to service $(67 \%)$. In another study (Rahman et al. 1997), prevalence of brucellosis was the highest in the buffaloes with retained placenta $(7.1 \%)$ and the lowest in repeat breeder buffaloes $(1.2 \%)$.

The results of this study show that brucellosis is widespread in cattle and buffaloes of Punjab (India). In India, cow slaughter is banned; as a result, either the dairy farmer has to keep the infected cattle at the farm, or these cattle are left on the roads spreading the disease to healthy cattle. Therefore, the only alternative to control and eradicate the disease from the healthy population is a statutory mass vaccination programme.

\section{Epidemiologická studie bovinní brucelózy v Pandžábu (Indie) s využitím mléčného ELISA testu}

Bovinní brucelóza, zpo̊sobovaná Brucella abortus, je významná zoonóza, které se projevuje poruchami reprodukce, což způsobuje farmářům závažné ekonomické ztráty. Náhodný průzkum s využitím testovacího software Survey Toolbox byl proveden za účelem provedení epidemiologické studie brucelózy v Pandžábu (Indie). Byl využit postup dvojitého výběru vzorků. V první fázi byli ze všech vesnic v Pandžábu náhodně vybráni farmáři a následně byli vybráni majitelé a zvírata z jednotlivých farem, taktéž pomocí systematického náhodného výběru. Celkem bylo vybráno 32 vesnic, z kterých bylo 345 zvířat testováno (cca $5 \%$ ). Získané vzorky mléka byly testovány na prítomnost protilátek proti brucele pomocí ELISA testu. Relativní prevalence brucelózy byla 18,26 \% (skutečná prevalence - 17,68 \%). Prevalence v centrální oblasti státu byla významně vyšší, tj. $23,2 \%\left(\chi^{2}=11,34, p<0,01\right)$ ve srovnání s $14,2 \%$ v podhưríi a 5,8 \% v suchých zavlažovaných oblastech. Prevalence výskytu brucelózy byla nevýznamně vyšší $\left(\chi^{2}=1,029, p=0,310\right)$ u skotu $(20,67 \%)$ ve srovnání s buvoly $(16,41$ $\%)$. U obou druhů vzrůstala s věkem $\left(\chi^{2}=8,572, p<0,05\right)$. Byla zjištěna významná souvislost mezi onemocněním a aborty $\left(\chi^{2}=22,322, p<0,01\right)$. Nejvyšší počet abortů kvůli brucelóze byl pozorován ve více než 6 měsících gestace $(95,7 \%)$. Toto onemocnění statisticky významně souviselo s retencí placenty $\left(\chi^{2}=8,477, p<0,01\right)$, ale nebyla zjištěna významná souvislost mezi onemocněním a zhoršeným zabřezáváním $\left(\chi^{2}=0,044, p=0,834\right)$. Výsledky studie naznačují, že přesná epidemiologická situace může být zjišt’ována s využitím vícestupňového testování za pomoci mléčného ELISA testu.

\section{Acknowledgement}

The study was supported by Project Directorate on Animal Disease Monitoring and Surveillance, Indian Council of Agricultural Research, New Delhi.

\section{References}

AHMAD R, MUNIR MA 1995: Epidemiological investigations of brucellosis in Pakistan. Pakistan Vet J 15: $169-172$

ALTON GG, JONES LM, ANGUS RD, VERGER JM 1988: Techniques for the brucellosis laboratory. Institut National de la Recherche Agronomique (INRA), Paris, 190 p.

BACHH AS, NOWSHERI MA, RASHID A, RAINA AK, WANI S 1988: Seroprevalence of brucellosis in exotic cattle in Kashmir. Indian J Comp Microbiol Immunol Infect Dis 9: 23-27 
CAMERON A 1999: Survey toolbox for livestock diseases - a practical manual and software package for active surveillance in developing countries. Canberra, Australian Centre for International Agricultural Research. ACIAR Monograph 54: 330

CHATTERJEE A, DE BN, MONDAL P, BIDYANTA JC, CHAKRABORTY MK, NANDY AK, SEN GP 1986: Studies on seroprevalence on bovine brucellosis in rural West Bengal. Indian Vet J 63: 95-100

DEAN AG, ARNER TG, SANGAM S, SUNKI GG, FRIEDMAN R, LANTINGA M, ZUBIETA JC, SULLIVAN KM, SMITH DC 2002: Epi Info 2002: a database and statistics program for public health professionals for use on Windows 95, 98, NT and 2000 computers. Centre for Disease Control and Prevention, Atlanta, Georgia

DHAND NK, GUMBER S, SINGH BB, ARADHANA, BAL MS, KUMAR H, SHARMA DR, SINGH J, SANDHU KS 2005: A study on the epidemiology of brucellosis in Punjab (India) using survey toolbox. RevOff Int Epizoot 24: 879-885

GUMBER S, ARADHANA DHAND NK, SANDHU KS 2004: Village level study of bovine brucellosis in Punjab (India) by bulk milk analysis. Indian J Anim Sci 74: 843-844

HUBER JD, NICOLETTI P 1986: Comparison of the results of card, rivanol, complement-fixation, and milk ring tests with the isolation rate of Brucella abortus form cattle. Am J Vet Res 47: 1529-1531

JHA VC, THAKUR RP, YADAV JN 1993: Seroprevalence of brucellosis in cattle and buffaloes in cattle and buffaloes in the Koshi Hills of Nepal. Vet Rev Kathmandu 8: 17-19

MCDERMOTT JJ, DENG KA, JAYATILEKA TN, EL JACK MA 1987a: A cross sectional cattle disease study in Kongor rural council, Southern Sudan. I. Prevalence estimates and age, sex and bred associations or brucellosis and contagious bovine pleuropneumonia. Prev Vet Med 5: 111-123

MCDERMOTT JJ, DENG KA, JAYATILEKA TN, EL JACK MA 1987b. A cross sectional cattle disease study in Kongor rural council, Southern Sudan. II. Brucellosis in cows: associated factors, impact on production and disease control considerations. Prev Vet Med 5: 125-132

PAUL A 1980: The Epidemiology of bovine brucellosis. Adv Vet Sci Comp Med 24: 75

RADOSTITS OM, GAY CC, BLOOD DC, HINCHCLIFF KW 2000: Veterinary medicine: a textbook of the diseases of cattle, sheep, pigs, goats and horses. $9^{\text {th }}$ ed. W. B. Saunders, London, $1877 \mathrm{p}$.

RAHMAN MA, ISLAM MS, ALAM MGS, SHAMSUDDIN M 1997: Seroprevalence of brucellosis in the buffalo (Bubalus bubalis) of a selected area in Bangladesh. Buffalo J 13: 209-214

ROBERTS SJ 1999: Veterinary obstetrics and genital diseases (Theriogenology). $2^{\text {nd }}$ ed. CBS publishers and distributors, New Delphi, India, pp. 499

ROMERO C, PARDO M, GRILLO MJ, DIAT R, BLASCO JM, LOPEZ GONI L 1995: Evaluation of PCR and Indirect Enzyme Linked Immunosorbent Assay on milk samples for diagnosis of brucellosis in dairy cattle. J Clinical Microbiol 33: 3198-3200

SAINI SS, SHARMA JK, KWATRA MS 1992: Assessment of some management factors responsible for prevalence of brucellosis among traditionally managed animal population of Punjab. Indian J Anim Sci 62: $832-834$

SANDHU KS, FILIA G, SHARMA DR, DHAND NK, SINGH J, SAINI SS 2001: Prevalence of brucellosis among dairy animals of Punjab. Indian J Comp Microbiol Immunol Infect Dis 22: 160-161

SHARMA JK, SAINI SS 1995: Seroprevalence of brucellosis among farm animals of Punjab. Indian Vet J 72: $881-882$

SHARMA RK, KUMAR A, THAPLIYAL DC, SINGH SP 2003: Sero-epidemiology of brucellosis in bovines. Indian J Anim Sci 73: 1235-1237

SHARMA S, ALKA, MAHAJAN V, VERMA S, KAUR K, MEENAKSHI, KUMAR H 2007: Screening of dairy farms of Punjab (India) for brucellosis and paratuberculosis. Indian Vet J 84: 315-316

SHARMA VD, SETHI MS, YADAV MP, DUBE DC 1979: Sero-epidemiological investigations on brucellosis in the states of Uttar Pradesh (U.P.) and Delphi (India). Int J Zoonos 6: 75-81

SILVA I, DANGOLLA A, KULACHELVY K 2000: Seroepidemiology of Brucella abortus infection in bovids in Sri Lanka. Prev Vet Med 46: 51-59

SINGH BB, SHARMA S, KUMAR H, DHAND NK 2004a: Surveillance of diseases in organized dairy farms of Punjab. J Res Punjab Agric Univ 41: 490-494

SINGH G, SHARMA DR, DHAND NK 2004b: Seroprevalence of bovine brucellosis in Punjab. Indian Vet J 81: 620-623

SINGH G, SHARMA DR, SANDHU KS, DHAND NK 2002: Economic losses occurring due to bovine abortions in Punjab. In: 10th International Congress of Asian-Australasian Association of Animal Production Societies, 23-27 September. Ashoka Hotel, New Delhi, India

SRINIVASA RT, RAMA DV, MADHU BR, NARASIMHA RAV 1999: Comparison of rapid plate agglutination standard tube agglutination and dot ELISA tests for the detection of antibodies to brucella in bovines. Indian Vet J 76: 255-256

VANZINI VR, AGUIRRE NP, VALENTINI BS, TORIONIDE ES, LUGARESI CI, MARCHESINO MD, NIELSEN K, DE ECHAIDE ST 2001:Comparison of an indirect ELISA with the Brucella milk ring test for detection of antibodies to Brucella abortus in bulk milk samples. Vet Microbiol 82: 55-60 
